๑ Entomologica Fennica. 12.X.1993

\title{
Diptera in mines and other cave systems in southern Norway
}

\author{
Jostein Kjærandsen
}

Kjærandsen, J. 1993: Diptera in mines and other cave systems in southern Norway. - Entomol. Fennica 4:151--160.

The dipterous fauna in 32 mines, 5 caves and some other cave systems in southern Norway has been studied with regard to species composition and periodicity. Some 20000 specimens belonging to 80 species in 18 families were recorded. Mycetophilidae (95.0\%), Culicidae (3.2\%) and Heleomyzidae $(1.3 \%)$, dominated. With the exception of Speolepta leptogaster (Winnertz, 1863) (Mycetophilidae), a possible troglophile, all species must be regarded as trogloxenes, most of them habitual trogloxenes inhabiting cave systems for hibernation. Some differences regarding species composition in different cave systems and between western and eastern Norway were demonstrated. Seasonal occurrence and sex-ratios reflect different life cycle strategies and seasonal adaptations among the habitual trogloxenes: hibernators, (Mycetophilidae, Culicidae), aestivators (Limoniidae, Bolitophilidae), species which seek cave systems independent of sex and season (Heleomyzidae, Trichoceridae), and opportunists (Chironomidae, Phoridae?, Dixidae?). Species belonging to other families are most likely accidental trogloxenes.

Jostein Kjaerandsen, Museum of Zoology, University of Bergen, Muséplass 3, N-5007 Bergen, Norway

\section{Introduction}

Diptera, like several other invertebrates, are known to inhabit caves and mines. The dipterous fauna in caves in continental Europe and the British Isles is well documented (e.g. Hazelton 1955-60, 1960, 1961, 1963, 1965a, 1965b, Tollet 1955, 1959, Burghele-Balacesco 1965, 1966a, $1966 \mathrm{~b})$, and the fauna in mines has also been studied (e.g. Husson 1936, 1947, Plassmann \& Weber 1988). In Fennoscandia however, invertebrates inhabiting cave systems are poorly known. A few species lists from caves, including Diptera, have been published by Krogerus (1926) from Finland, by Gislén \& Brinck (1950) from
Sweden and by Østbye et al. (1987) and Hippa \& Koponen (1988) from Norway. So far nothing has been published on Diptera in mines.

Most Diptera occurring in caves and mines hibernate or aestivate in these environments and thus only inhabit the cave systems for part of their lives. Such animals are referred to as habitual trogloxenes. Others are occasional inhabitants, entering underground environments only when particular habitats occur (e.g. bat guano, streams). They are referred to as opportunists. Yet others are simply accidental visitors. Only a few European Diptera species are known to establish permanent populations in cave systems. These are referred to as troglophiles or troglobites (e.g. 

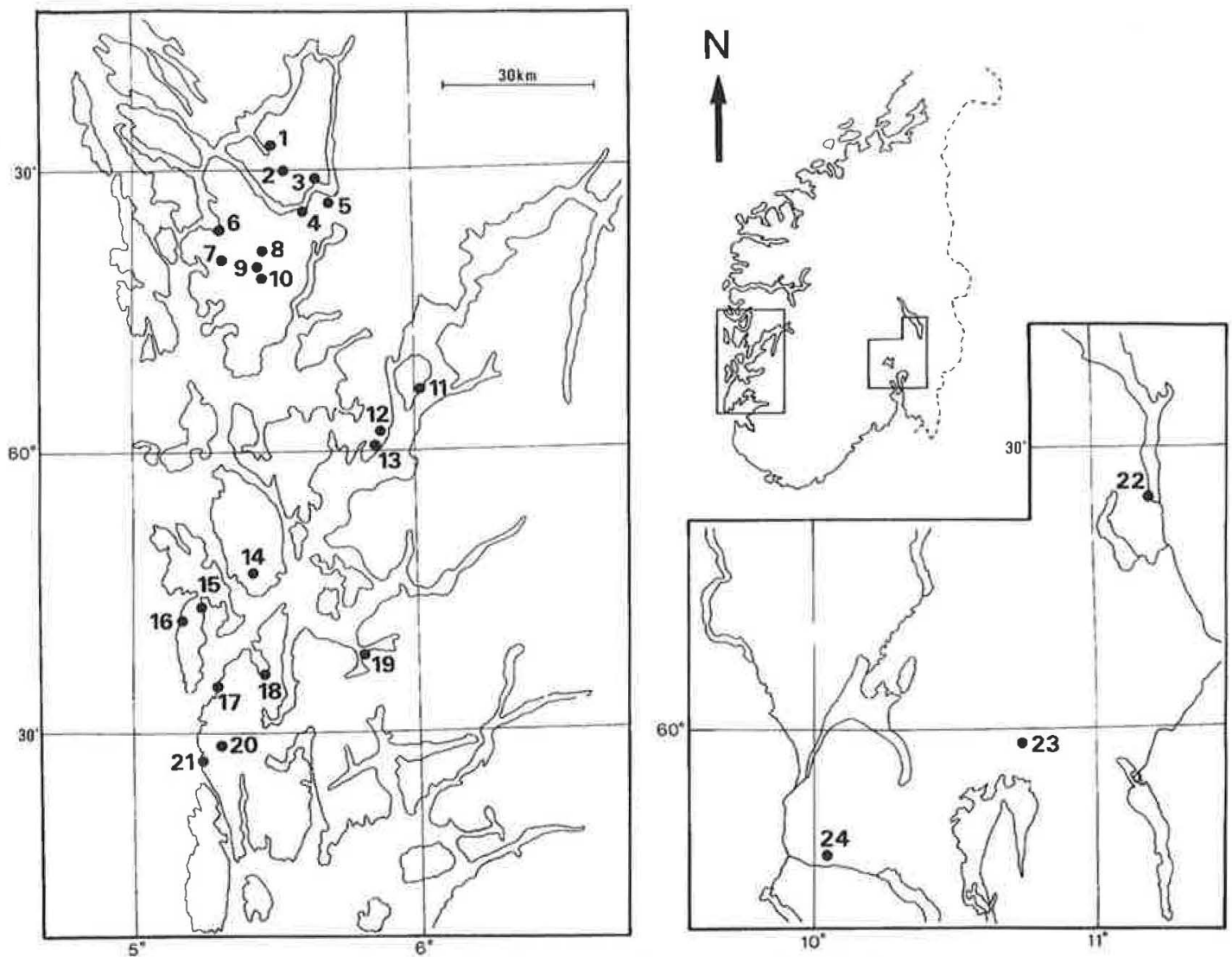

Fig. 1. Locations of cave systems visited in southern Norway. The numbers correspond to the localities given in Table 1.

Matile 1970, Jefferson 1983, Østbye et al. 1987). The normal habitat for most cavernicole Diptera is thus evidently not caves, but any natural or artificial system of cavities or fissures below the superficial soil layer where they find suitable environmental conditions (see Racovitza 1907, Glennie 1965). The term cave system as used here refers to all such types of underground cavities.

The aim of the present survey was to improve the knowledge of Diptera dwelling in different cave systems in Norway, to study whether different species occurred in different cave systems, and to examine which life cycle strategies and seasonal adaptations their occurrence might reflect. Data on preferred sites and resting positions within some of the mines is presented elsewhere.

\section{Study area and cave systems}

Adult Diptera were collected from 21 localities in the counties of Hordaland and Rogaland in Southwest Norway, and from 3 localities in the counties of Akershus and Buskerud in Southeast Norway (Fig. 1). In Hordaland only a few minor caves are known. However, there are several mines originating from the late 19th and early 20th centuries (Sandvik 1977). In Southeast Norway a few small caves are known (e.g. Østbye et al. 1987). A total of 32 mines, 3 limestone caves, 2 soapstone caves (partly manmade in the Stone Age), 6 concrete bunkers (made during the second World War) and some screes and smaller rock fissures were surveyed (Table 1).

The western coast of Norway has an Atlantic climate, with heavy rainfall and only shorter pe- 
riods with frost and snow cover during winter. Eastern Norway has a more continental climate with dry and cold winters, usually with frost and snow cover prevailing.

\section{Material and methods}

The survey includes samples of adult specimens, collected in cave systems in the period 19901992. Localities no. 8, 9 and 10 were sampled many times at all seasons, while most other localities were visited only once, in winter (Table 1). Only the walls and roof were examined, leav- ing out larval habitats in bodies of water. A pooter was found suitable for collecting the insects and showed a very high efficiency for small and medium sized insects. Only large species such as crane flies had to be handpicked. In 14 galleryshaped cave systems a standardized sampling method was used. At every fifth metre from the entrance, one metre sections along the walls and roof were closely examined and all observed insects collected with the pooter. This sampling method should enable semi-quantitative comparisons of the material. Approximately $67 \%$ of the total material was collected using this method. In the other cave systems the walls and roof were

Table 1. Cave systems visited. $L M=$ large mines, i.e. penetrating more than 20 metres inwards, $S M=s m a l l$ mines, i.e. 20 metres or shorter, $\mathrm{CA}=$ caves, $\mathrm{BU}=$ bunkers, $\mathrm{SF}=$ screes and fissures.

\begin{tabular}{|c|c|c|c|c|c|}
\hline $\begin{array}{l}\text { Loc. } \\
\text { no. }\end{array}$ & Locality & Municipality & $\begin{array}{l}\text { UTM reference } \\
32 \mathrm{~V}\end{array}$ & $\begin{array}{l}\text { Number, type and length of gallery } \\
\text { from entrance to bottom }\end{array}$ & Date \\
\hline 1 & Nonås & Osterøy & LN 075169 & 1 LM ( 100m) & 13.III.90 \\
\hline 2 & Skistad & Osterøy & LN 098122 & $1 \mathrm{LM}(25 \mathrm{~m})$ and $1 \mathrm{SM}(15 \mathrm{~m})$ & $\begin{array}{l}13.111 .90 \\
\text { and } 08 . X 1.90\end{array}$ \\
\hline 3 & Skaftå & Osterøy & LN 144073 & $1 \mathrm{LM}(\sim 1000 \mathrm{~m})$ & $08 . X 1.90$ \\
\hline 4 & Trengereid & Bergen & LN 135042 & 1 LM ( 100m) & 22.I.91 \\
\hline 5 & Langhelle & Vaksdal & LN 192063 & $1 \mathrm{CA}(19 \mathrm{~m})$, limestone & 22.1 .91 \\
\hline 6 & Bergen & Bergen & KM 974999 & 1 LM $(\sim 100 \mathrm{~m})$ & 01.11 .91 \\
\hline 7 & Trollhaugen & Bergen & KM 976928 & 1 LM (25m) & $08 . X 1.91$ \\
\hline 8 & Haukeland & Bergen & LM 046962-047963 & $\begin{array}{l}2 \operatorname{LM}(160 \mathrm{~m}, 85 \mathrm{~m}) \text { and } \\
2 \operatorname{SM}(20 \mathrm{~m}, 15 \mathrm{~m})\end{array}$ & $\begin{array}{l}11 . X .90 \text { to } \\
14.111 .92\end{array}$ \\
\hline 9 & Riple & Bergen & LM 036918 & $1 \mathrm{LM}(155 \mathrm{~m})$ and $2 \mathrm{SM}(9.5 \mathrm{~m}, 3 \mathrm{~m})$ & $\begin{array}{l}11 . X .90 \text { to } \\
14.111 .92\end{array}$ \\
\hline 10 & Gymmeland & Bergen & LM 040905-043909 & $2 \mathrm{LM}(65 \mathrm{~m}, 22 \mathrm{~m})$ & $\begin{array}{l}18 . \mid I I .90 \text { to } \\
14 . \mid I I .92\end{array}$ \\
\hline 11 & Varaldsøy & Kvinnherad & LM 345671 & $2 \mathrm{SF}(1 \mathrm{~m}, 2 \mathrm{~m})$ & 10.111 .91 \\
\hline 12 & Atramadalen & Kvinnherad & LM 260595 & $3 \mathrm{LM}(\sim 100 \mathrm{~m}, \sim 80 \mathrm{~m}, 40 \mathrm{~m})$ & 09.111 .91 \\
\hline 13 & Fugleberget & Kvinnherad & LM 249577 & $2 \mathrm{CA}(12 \mathrm{~m}, 5 \mathrm{~m})$, soapstone & $09 . \mid I I .91$ \\
\hline 14 & Litlabø & Stord & KM 992337 & 1 LM $(85 m)$ & $11 . \mid I .91$ \\
\hline 15 & Hidle & Bømlo & KM 889273 & $1 \mathrm{SM}(19 \mathrm{~m})$ & 10.II.91 \\
\hline 16 & Lykling & Bømlo & KM 846249-852268 & $1 \mathrm{LM}(25 \mathrm{~m})$ and $2 \mathrm{SM}(15 \mathrm{~m}, 10 \mathrm{~m})$ & $\begin{array}{l}04 . X .90 \text { and } \\
10.11 .91\end{array}$ \\
\hline 17 & Nordbø & Sveio & KM 906102 & $4 \mathrm{BU}(9.5 \mathrm{~m}, 5 \mathrm{~m}, 5 \mathrm{~m}, 1 \mathrm{~m})$ & $21 . X 11.90$ \\
\hline 18 & Førde & Sveio & LM 013139-001134 & $4 \mathrm{SF}(\sim 3-10 \mathrm{~m})$ & $\begin{array}{l}02.1 .92 \text { and } \\
04.1 .92\end{array}$ \\
\hline 19 & Dreganes & Ølen & LM 193162 & $2 \mathrm{SM}(10 \mathrm{~m}, 8 \mathrm{~m})$ and $1 \mathrm{BU}(5 \mathrm{~m})$ & $\begin{array}{l}03 . \times .90 \text { to } \\
05.1 .92\end{array}$ \\
\hline 20 & Vikse & Haugesund & KL 900004 & $1 \mathrm{SM}(3 \mathrm{~m})$ & $\begin{array}{l}11 . X 1.90 \text { and } \\
09.11 .91\end{array}$ \\
\hline 21 & Kvalsvik & Haugesund & KL 870950 & $1 \mathrm{BU}(8 \mathrm{~m})$ & $09 . X 11.91$ \\
\hline 22 & Minnesund & Eidsvoll & PN 209006 & $\begin{array}{l}3 \mathrm{LM}(2 \mathrm{x} \sim 100 \mathrm{~m}, 81 \mathrm{~m}) \text { and } \\
2 \mathrm{SM}(18 \mathrm{~m}, 6 \mathrm{~m})\end{array}$ & 15.11 .92 \\
\hline 23 & Båntjern & Oslo & NM 954486 & $1 \mathrm{CA}(\sim 70 \mathrm{~m})$, limestone & 15.II.92 \\
\hline 24 & Svarttjern & Nedre Eiker & NM 580266 & $1 \mathrm{CA}(-30 \mathrm{~m})$, limestone & 17.II.92 \\
\hline
\end{tabular}


Table 2. Numbers of adult Diptera from different cave systems in Southwest and Southeast Norway. The grouping of the cave systems is explained in Table 1. An asterisk behind the proportion of females denotes significant deviation from $50 \%\left(\chi^{2}\right.$-test $) .{ }^{*}=P<0.05,{ }^{* \star}=P<0.01,{ }^{* * *}=P<0.001$.

\begin{tabular}{|c|c|c|c|c|c|c|c|c|c|c|c|}
\hline \multirow[b]{2}{*}{ Cavities / samples: } & \multicolumn{5}{|c|}{ Southwest Norway } & \multicolumn{3}{|c|}{ Southeast Norway } & & & \multirow[b]{2}{*}{$\begin{array}{l}\text { Percent } \\
\text { females }\end{array}$} \\
\hline & $\begin{array}{c}\text { LM } \\
16 / 44\end{array}$ & $\begin{array}{c}\text { SM } \\
11 / 17\end{array}$ & $\begin{array}{l}\text { CA } \\
3 / 3\end{array}$ & $\begin{array}{l}\text { BU } \\
6 / 5\end{array}$ & $\begin{array}{l}\text { SF } \\
6 / 4\end{array}$ & $\begin{array}{l}\text { LM } \\
3 / 3\end{array}$ & $\begin{array}{l}\text { SM } \\
2 / 2\end{array}$ & $\begin{array}{l}\text { CA } \\
2 / 2\end{array}$ & \multicolumn{2}{|c|}{ Total } & \\
\hline \multicolumn{12}{|l|}{ Bolitophilidae } \\
\hline \multicolumn{12}{|l|}{ Mycetophilidae } \\
\hline Mycetophila evanida Laštovka, 1972 & 17 & 3 & - & - & - & 1 & - & - & 21 & 0.11 & 52 \\
\hline Mycetophila ocellus Walker, 1848 & - & - & - & 7 & 1 & - & - & - & 8 & 0.04 & 25 \\
\hline Mycetophila ornata Stephens, 1829 & 1 & 1 & - & 6 & - & 1 & - & - & 9 & 0.05 & 33 \\
\hline Mycetophila signatoides Dziedzicki, 1884 & 3 & 11 & - & - & - & - & - & - & 14 & 0.07 & 64 \\
\hline Mycetophila unipunctata Meigen, 1818 & 27 & 16 & 1 & - & 6 & - & - & - & 50 & 0.26 & 40 \\
\hline Anatella ankeli Plassmann, 1987 & 3 & - & - & - & - & - & - & - & 3 & 0.02 & 67 \\
\hline Exechia confinis Winnertz, 1863 & 7 & - & - & - & 3 & 8 & 3 & - & 21 & 0.11 & 43 \\
\hline Exechia contaminata Winnertz, 1863 & 2 & 1 & - & - & - & - & - & - & 3 & 0.02 & 67 \\
\hline Exechia cornuta Lindström, 1914 & 6 & 1 & 1 & - & - & - & - & - & 8 & 0.04 & 50 \\
\hline Exechia dizona Edwards, 1924 & 30 & 6 & 5 & - & 3 & - & 2 & - & 46 & 0.24 & 57 \\
\hline Exechia exigua Lundström, 1909 & 493 & 31 & 4 & - & 1 & 1 & - & - & 530 & 2.71 & $55^{*}$ \\
\hline Exechia festiva Winnertz, 1863 & 261 & 189 & 106 & 1 & 8 & - & - & - & 565 & 2.89 & $57^{* * *}$ \\
\hline Exechia frigida (Boheman, 1865) & 8 & 4 & - & - & - & - & - & - & 12 & 0.06 & 67 \\
\hline Exechia fusca (Meigen, 1804) & 8 & 2 & - & 2 & 2 & - & - & - & 14 & 0.07 & 36 \\
\hline Exechiopsis clypeata (Lundström, 1911) & 41 & - & - & - & - & 3 & 6 & 1 & 51 & 0.26 & 53 \\
\hline Exechiopsis distendens (Lackschewitz, 1937) & 74 & 2 & 18 & - & - & - & - & - & 94 & 0.48 & 46 \\
\hline Exechiopsis dryaspagensis Chandler, 1977 & 27 & - & - & - & - & - & - & - & 27 & 0.14 & 52 \\
\hline Exechiopsis fimbriata (Lundström, 1909) & 226 & 4 & 2 & - & - & 5 & - & - & 237 & 1.21 & $68^{\star \star \star}$ \\
\hline Exechiopsis hammi (Edwards, 1925) & 34 & 2 & 1 & - & - & 1 & 1 & - & 39 & 0.20 & 59 \\
\hline Exechiopsis indecisa (Walker, 1856) & 3 & - & - & - & 1 & 1 & - & - & 5 & 0.03 & 40 \\
\hline Exechiopsis intersecta (Meigen, 1818) & 4 & 1 & 1 & - & - & 3 & - & - & 9 & 0.05 & 33 \\
\hline Exechiopsis januarii (Lundström, 1913) & - & - & - & - & - & 12 & 3 & 10 & 25 & 0.13 & 64 \\
\hline \multicolumn{12}{|l|}{ Exechiopsis lackschewitziana } \\
\hline (Stackelberg, 1948) & 2 & - & - & - & - & - & 1 & 1 & 4 & 0.02 & 50 \\
\hline Exechiopsis ligulała (Lundström, 1913) & 16 & - & 1 & - & - & 1 & - & - & 18 & 0.09 & 44 \\
\hline \multicolumn{12}{|l|}{ Exechiopsis pseudopulchella } \\
\hline (Lundström, 1912) & 38 & 1 & 2 & - & - & - & - & - & 41 & 0.21 & 46 \\
\hline Exechiopsis subulata (Winnertz, 1863) & 1568 & 31 & 9 & - & - & 16 & - & 1 & 1625 & 8.31 & $47^{*}$ \\
\hline Exechiopsis pollicata (Edwards, 1925) & 2 & - & - & - & - & 2 & - & - & 4 & 0.02 & 50 \\
\hline Pseudexechia aurivernica Chandler, 1978 & 354 & 93 & 8 & 2 & 9 & - & - & - & 466 & 2.38 & $56^{\star \star}$ \\
\hline Pseudexechia trisignata (Edwards, 1913) & 4 & - & 1 & - & 16 & - & - & - & 21 & 0.11 & $71^{\star}$ \\
\hline Rymosia affinis Winnertz, 1863 & 23 & 77 & 1 & 1 & - & - & - & - & 102 & 0.52 & 45 \\
\hline Rymosia fasciata (Meigen, 1804) & 9665 & 2306 & 1052 & 807 & 6 & 399 & 182 & 6 & 14423 & 73.76 & $43^{\star \star \star}$ \\
\hline Rymosia placida Winnertz, 1863 & 11 & 6 & - & - & - & 1 & 1 & - & 19 & 0.10 & $21^{*}$ \\
\hline Tarnania dziedzickii (Edwards, 1941) & 36 & 9 & - & - & - & - & - & - & 45 & 0,23 & 62 \\
\hline Tarnania fenestralis (Meigen, 1818) & 12 & - & - & - & - & - & - & - & 12 & 0,06 & 42 \\
\hline \multicolumn{12}{|l|}{ Trichoceridae } \\
\hline Trichocera maculipennis Meigen, 1818 & 6 & - & - & 1 & - & - & - & - & 7 & 0.04 & 43 \\
\hline \multicolumn{12}{|l|}{ Dixidae } \\
\hline Dixa nebulosa Meigen, 1830 & - & - & - & - & - & - & - & 3 & 3 & 0.02 & 100 \\
\hline \multicolumn{12}{|l|}{ Culicidae } \\
\hline Culex pipiens Linnaeus, 1758 & 163 & 75 & 25 & 4 & 14 & 43 & 44 & 11 & 379 & 1.94 & $100^{* * *}$ \\
\hline Culex territans Walker, 1856 & 74 & 27 & 6 & - & 7 & - & 3 & 5 & 122 & 0.62 & $100^{\star \star \star}$ \\
\hline Culiseta alaskaensis (Ludlow, 1906) & - & - & - & - & 2 & 20 & 10 & 4 & 36 & 0.18 & $100^{\star \star \star}$ \\
\hline Culiseta annulata (Schrank, 1776) & 8 & 37 & 3 & 11 & 36 & - & - & - & 95 & 0.49 & $100^{* * *}$ \\
\hline \multicolumn{12}{|l|}{ Chironomidae } \\
\hline Zavrelimyia nubila (Meigen, 1830) & 6 & - & $=$ & $=$ & - & - & - & - & 6 & 0.03 & 83 \\
\hline \multicolumn{12}{|l|}{ Syrphidae } \\
\hline Eristalis tenax (Linnaeus, 1758) & 7 & 7 & - & 1 & - & - & 6 & - & 15 & 0.08 & $100^{\star * \star}$ \\
\hline Heleomyzidae & & & & & & & & & & & \\
\hline Scoliocentra brachypterna (Loew, 1873) & 4 & - & 1 & - & - & - & - & 4 & 9 & 0.05 & 44 \\
\hline Heleomyza serrata (Linnaeus, 1758) & 199 & 7 & 14 & - & - & 7 & 7 & 11 & 245 & 1.25 & $64^{* \ldots}$ \\
\hline Other species ${ }^{11}$ & 27 & 8 & - & 2 & 1 & 5 & - & 3 & 46 & 0.24 & \\
\hline Totals & 13515 & 2958 & 1262 & 845 & 116 & 530 & 269 & 60 & 19555 & 100 & \\
\hline
\end{tabular}


more briefly examined by moving slowly inwards while collecting either all observed insects, or representative samples where dense aggregations occurred. An ordinary hand lamp was used to illuminate the walls during sampling. The insects in the pooter tube were killed by adding $70 \%$ alcohol. Most identifications were made under a Wild M5A lupe with magnification range $6-100 \times$, but some of the material was mounted in Canada balsam on slides and examined under a Leitz Laborlux K microscope. The material is in the Museum of Zoology, University of Bergen.

\section{Results}

\subsection{The species}

Cave systems sustain a rich Diptera fauna in southern Norway. A total of 19555 adult specimens belonging to 80 species in 18 families were found (Table 2). Of these, $95.2 \%$ belong to 50 species of fungus gnats (Sciaroidea). Eight species, all belonging to the tribus Exechiini (Mycetophilidae) constitute about $92 \%$ of the material. Four species of mosquitoes (Culicidae) make up $3.2 \%$, and four species of Heleomyzidae make up $1.3 \%$.

\subsection{Seasonal occurrence and sex-ratios}

Analysis of seasonal occurrence showed that most species evidently sought refuge underground for hibernation. In the most extensively studied mines at locs 8,9 and 10, hibernating fungus gnats and mosquitoes were present from early October to early May. The greatest numbers were obtained in November and December. The hibernators penetrated the mines to various depths. Most specimens remained in the mines until late April, and seemed to leave rapidly in early May. Among the hibernating species only a few specimens of Exechiopsis, Tarnania fenestralis (Meigen, 1818) (Mycetophilidae) and Culex pipiens Linnaeus, 1758 (Culicidae) were found in the mines during summer. Females of Bolitophila cinerea Meigen, 1818 (Bolitophilidae) were only found in summer, together with a few specimens of Dolichopeza albipes Strøm, 1768 (Tipulidae), Limoniidae and Zavrelimyia nubila (Meigen, 1830) (Chironomidae). These aestivators did not penetrate far beyond the entrance. Heleomyza serrata (Linnaeus, 1758) (Heleomyzidae) was found throughout the year, with maximum abundance in summer. Larvae of Speolepta leptogaster (Winnertz, 1863) (Mycetophilidae) were frequent in winter, and pupae in spring. A single adult was taken in June.

Both sexes were recorded in species belonging to Mycetophilidae and Heleomyzidae, and most species of Mycetophilidae showed a sexratio close to 50:50. The proportion of females in species of Rymosia and Exechiopsis was generally slightly lower than in species of Exechia and Pseudexechia. One notable exception was, however, Exechiopsis fimbriata which was composed of $68 \%$ females $(n=237, P<0.001)$. In Heleomyza serrata the proportion of females was $64 \%(n=245, P<0.001)$. The families Bolitophilidae, Culicidae and Syrphidae were represented by females only.

\footnotetext{
1) Other species: Tipulidae: Dolichopeza albipes Strøm, $176820^{\circ} \sigma^{7}$. Limoniidae: Limonia nubeculosa Meigen, 1804 1o, cf. Elliptera sp. 10', Limoniidae sp. 10'. Mycetophilidae: Speolepta leptogaster (Winnertz, 1863) 107, Macrobrachius sp.n.? 10', Mycetophila cf. blanda Winnertz, 1863 1o, Mycetophila curviseta Lundström, 1911 10', Mycetophila ruficollis group 2o, Mycetophila cf. sordida van der Wulp, 1874 1o, Phronia fusciventris Van Duzee, $192820^{\circ} 0^{\top}$, Phronia sp. 1o, Anatella sp. 1o, Exechia spinigera group 1o, Exechiopsis ingrica (Stackelberg, 1948) 10', Exechiopsis cf. landrocki (Lundström, 1912) 1@, Exechiopsis pseudindecisa Laštovka \& Matile, $197410^{\prime} 10$, Rymosia cf. winnertzi Barendrecht, 1938 1 . Sciaridae: Lycoriella cf. solani (Winnertz, 1871) 20'o'. Psychodidae: Psychoda lobata Tonnoir, $192220^{\prime \prime} \sigma^{\prime}$, Psychoda phalaenoides (Linnaeus, 1758) 10', Psychoda sp. 10. Trichoceridae: Trichocera implicata Dahl, 1976 10', Trichocera hiemalis (De Geer, 1776) 10'. Chironomidae: Diamesa bohemani Goetghebuer, 1932 1\%, Chaetocladius sp. 1q. Thienemannia gracilis Kieffer, 1909 1o. Empididae: Clinocera appendiculata (Zetterstedt, [1838]) 1o. Lonchopteridae: Lonchoptera lutea Panzer, 1809 1o. Phoridae: Megaselia sp. 2oo. Heleomyzidae: Heleomyza borealis (Boheman, 1865) 10', Suillia sp. 2qo. Sphaeroceridae: Copromyza roseri (Rondani, 1880) 10'. Drosophilidae: Drosophila phalerata Meigen, 1830 10, Leucophenga quinquemaculata Strobl, $189310^{\top 1} 1$. Calliphoridae: Calliphora vicina Robineau-Desvoidy, $183010^{7} 1$.
} 


\subsection{Species composition in different cave sys- tems}

The species composition did not vary considerably between the different cave systems, as nearly all abundant genera occurred in all systems examined (Table 3 ). As regards relative abundance some differences were apparent. Species of Exechiopsis seem to prefer larger mines and caves. The proportion of Rymosia is very high in all systems, except in screes and fissures. In screes and fissures species of Exechia, Pseudexechia, Culex and Culiseta dominated, although only a few specimens were found.

At species level, a few species within some of the abundant genera of Mycetophilidae indicated preferences regarding cave systems. $M y$ cetophila evanida Laštovka, 1972 was only found in mines, Exechia exigua Lundström, 1909 was mainly found in large mines and Pseudexechia trisignata (Edwards, 1913) seemed to prefer screes and fissures.

\subsection{Regional distribution patterns}

Some differences in species composition are apparent when cave systems in Southwest and Southeast Norway are compared (Fig. 2). Rymosia fasciata (Meigen, 1804) dominated in both areas, providing $74 \%$ and $67 \%$ of the material, respectively. Among Exechiopsis, E. subulata (Win-

Table 3. Relative abundance (\%) of genera making up more than $1 \%$ of the total in one or more of the different cave systems. $+/$ - denotes presence/absence of a taxon. The grouping of the cave systems is explained in Table 1.

\begin{tabular}{lrrrrr}
\hline & LM & SM & CA & BU & SF \\
\hline Mycetophila & + & 1 & + & 2 & 6 \\
Exechia & 6 & 7 & 9 & + & 15 \\
Exechiopsis & 15 & 2 & 4 & - & 1 \\
Pseudexechia & 3 & 3 & 1 & + & 22 \\
Rymosia & 72 & 80 & 80 & 96 & 5 \\
Culex & 2 & 5 & 4 & + & 18 \\
Culiseta & + & 1 & 1 & 1 & 33 \\
Heleomyza & 1 & + & 2 & - & - \\
Sample sizes & 14045 & 3227 & 1322 & 845 & 116 \\
\hline
\end{tabular}

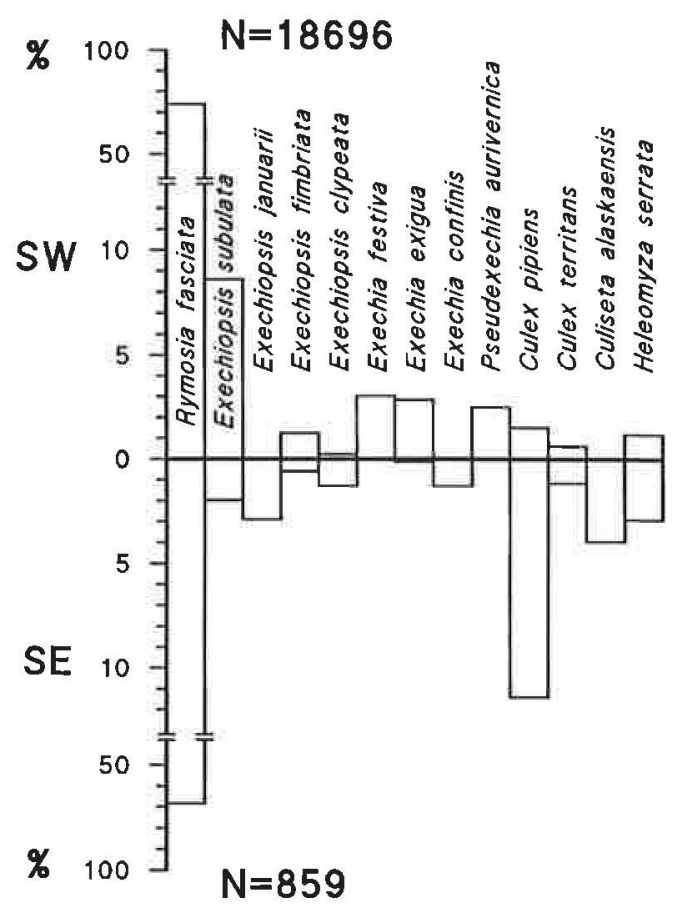

Fig. 2. Relative abundance (\%) of species making up more than $1 \%$ of the total in cave systems in either Southwest Norway (SW) or Southeast Norway (SE). Note the axis break.

nertz, 1863) dominated in southwestern cave systems while E. januarii (Lundström, 1913) dominated in southeastern ones. In the southwest, several species of Exechia were commonly found, Exechia festiva Winnertz, 1863 and Exechia exigua being the most abundant. In the southeast, only a few specimens of this genus were found; most of them belong to Exechia confinis Winnertz, 1863. Pseudexechia aurivernica Chandler, 1978 ranked as the fifth most abundant species in the southwest; in the southeast no specimens of Pseudexechia were taken. Culex pipiens ranked sixth in the southwest, but second in the southeast. In the southeast, Culiseta alaskaensis (Ludlow, 1906) ranked third. This species was almost entirely replaced by the related Culiseta annulata (Schrank, 1776) in the southwest.

Two abundant fungus gnats, Rymosia affinis Winnertz, 1863 and Tarnania dziedzickii (Edwards, 1941), were only found in southern parts of Hordaland, the latter only at loc. 16 where both species were quite abundant. 


\section{Discussion}

According to Jefferson (1983), Diptera are the most numerous cavernicole animals occurring near the entrance. In southern Norway Mycetophilidae dominated both in number of species and in abundance, while Culicidae ranked second and Heleomyzidae third. This situation is generally found throughout Europe where many species of Mycetophilidae and some species of Culicidae and Heleomyzidae dominate (e.g. Tollet 1959). Among Mycetophilidae, species in the tribus Exechiini clearly dominate (e.g. Tollet 1955, Burghele-Balacesco 1966b, Plassmann \& Weber 1988), and according to Matile (1970), Rymosia fasciata undoubtedly is the most common dipterous dweller in cave systems throughout Europe.

In terms of species composition, the cave assemblage can be recognized as a fairly well defined community. IIowever, temporal variation in abundance and different sex-ratios reflect that the fauna in cave systems is composed of species with highly different life cycle strategies and seasonal adaptations. Jeannel (1926) called the association of species characteristically seen on the walls and roof near the entrance of cave systems the 'parietal association'. This association is composed of both hibernators, aestivators and species occurring independent of season. In southern Norway, nearly all species of Mycetophilidae and Culicidae evidently used cave systems only for hibernation. In central and southern Europe, on the other hand, many of the same or related species are found underground at various times through the year, often during summer (see e.g. Tollet 1955, 1959, Burghele-Balacesco $1965,1966 \mathrm{a}, 1966 \mathrm{~b})$. This probably reflects a different life cycle strategy in northern Europe, compared to southern Europe. In the warmer parts of southern Europe the hibernators are likely to extend the sojourn underground throughout the summer. They may also to a larger extent roost inside the entrance of caves during daytime in summer.

The occurrence of Bolitophila cinerea and Limonia nubeculosa Meigen, 1804 in summer concurs with records from throughout Europe, where many species of Bolitophila and Limonia nubeculosa are known as underground aestivators (Krogerus 1926, Husson 1936, 1947, Hazelton
1955-60, 1960, 1961, 1963, 1965a, 1965b, Tollet 1955, 1959, Burghele-Balacesco 1965, 1966a, 1966b, Hippa \& Koponen 1988, Plassmann \& Weber 1988). Only one species of Bolitophila, $B$. saundersi (Curtis, 1836), seem to occur in cave systems throughout the year (Tollet 1955, 1959). All others, including $B$. cinerea, are found only during summer. According to Matile (1970) Limonia nubeculosa is the most common aestivating species of Diptera in the Palaearctic region. Figures of thirty to fifty individuals per square metre on the walls of caves in France are observed (Matile 1970). It is surprising that only one specimen was taken during this study, but only the four large mines at localities no. 8, 9 and 10 were visited in summer.

According to Dahl (1970), adults of Trichoceridae are found in crevices and under stones when conditions are less favourable in winter, and a cool climate with high air humidity is important for the activity of the adults. Species of Trichoceridae are thus preadapted to cave systems and some species are regarded as habitual trogloxenes (e.g. Hutson 1978). In subboreal localities Trichocera maculipennis Meigen, 1818 flies in spring and autumn (Dahl 1970). However, it is recorded throughout the year in British caves (Hazelton 1955-60, 1960, 1961, 1963, 1965a, 1965b, Hutson 1978). Hence, the occurrence in northern cave systems does not seem to be restricted to hibernation or aestivation. Many corpses of Trichoceridae, probably belonging to this species, were observed several hundred metres from the entrance in the mine at loc. 3 .

Among the Heleomyzidae, entire genera, such as Scoliocentra Loew, 1862, Orbellia RobineauDesvoidy, 1830, Oecothea Haliday, 1837 and Eccoptomera Loew, 1862, show imaginal features connected with subterranean life (Hackman 1963). Their eyes are more or less reduced and the arista often conspicuously long. Many species are known to be saprophagous (Hackman 1963), and some of these are known to breed in cave systems (Matile 1970). However, Heleomyza serrata seem to belong to the parietal association as only adults are found inside cave systems (Jefferson 1983). This species was particulary abundant in the largest gallery at Haukeland (loc. 8 ), where great numbers of dead specimens, in various stages of fungal decomposition, were 
observed on the lower parts of the walls. Living individuals only made up a small proportion, even in summer.

It is something of a mystery why Heleomyza serrata and Trichocera maculipennis seek underground environments since their occurrence is nearly aseasonal and most individuals apparently perish without returning to the surface (see Jefferson 1983). This seems to confirm a death aggregation (thanatoses). Both these species are reported from vole burrows, where they are regarded as saprophagous (Hackman 1963). If the proximate factor when searching for vole burrows is negative phototaxis, as suggested for subterranean hibernating species (e.g. Tercafs \& Thinès 1973, Danks 1978), this could result in such accidental aggregation in cave systems. Another explanation might be an evolutionary dead end selection or "the ghost of competition past", where the habits of recent species have causal connection in evolutionary history of descent back to true cavernicole ancestors.

Zavrelimyia nubila can be regarded as an opportunist. The adults found in summer probably emerged from ponds located near the entrance.

Speolepta leptogaster is very common in cave systems throughout Europe where larvae are more frequently seen than the short lived adults (e.g. Hutson 1978, Jefferson 1983). The species is usually regarded as a troglophile. However, in Southwest Norway it seemed to leave the mines after hatching in spring, but lack of adults in the mines in summer may be due to the short lived adult stage (see Hutson et al. 1980, Jefferson 1983).

\subsection{Variation in species composition}

None of the species found are obligate cave dwellers, and the majority of the species pass their immature stages in habitats found exclusively outside cave systems. Thus, it is likely that the specific conditions in the surrounding biotopes largely define the species composition. Hence, their occurrence seems to be controlled by environmental conditions inside the cave systems and habitats in the geographical area outside rather than by the history of the cave systems. Each generation finds its way into the cave systems independent of previous genera- tions, contrasting with the history dependent occurrence of true cave dwellers. Exceptions might be Speolepta leptogaster and Heleomyza serrata which probably maintain history dependent populations in certain cave systems. Most cave systems were located in areas with deciduous or mixed forests. The lack of variation in species composition between the cave systems is thus not surprising. However, in the southern parts of Hordaland several cave systems were located in coastal heathland, dominated by Calluna vulgaris. This can explain the exclusive occurrence of Rymosia affinis and Tarnania dziedzickii in these cave systems, if they are restricted to heathland habitats.

The apparent difference in relative abundance between larger cave systems and fissures and screes is probably due to environmental conditions and accessibility. Species of Exechiopsis and Rymosia fasciata penetrated further inside large mine galleries than most other species. However, these species might also be abundant in fissures and screes if they aggregate in the innermost minute and unreachable cavities or fissures. Hence, only those species occurring near the entrance were found in fissures and screes.

The regional comparison of the fauna demonstrates some elements of eastern and western distribution patterns. Exechiopsis ingrica (Stackelberg, 1948) and Exechiopsis januarii found in Southeast Norway have been previously recorded from Finland and the European parts of the former USSR only (Hackman 1980, Soós \& Papp 1988), while Exechiopsis dryaspagensis Chandler, 1977 found in Southwest Norway, was previously known only from Great Britain (Soós \& Papp 1988). Pseudexechia aurivernica which was quite abundant in Southwest Norway, was previously known only from the British Isles, where it seems to have a northwestern distribution (Chandler 1978), and from northern Germany (Plassmann 1989). It is hard to conceive why mosquitoes were relatively much more abundant in Southeast Norway than in Southwest Norway. All four species are widespread throughout major parts of the Holarctic region (Soós \& Papp 1991). Hence, the switching from Culiseta annulata in Southwest Norway to Culiseta alaskaensis in Southeast Norway cannot be explained by distributional pattern in adjacent countries. 


\subsection{Life cycle strategies}

The environment inside the cave systems provides opportunities for prolonged survival of the reproductive stage during the period when suitable larval habitats are unavailable. Thus, cave systems are temporary resorts which may play an important role in maintaining populations of species with an entirely different ecology. The difference in sex-ratio between Mycetophilidae and Culicidae is probably connected with the different life histories of the species. Species within Exechiini seem to be mainly, if not entirely, associated with soft sporophores of Agaricales (Hackman \& Meinander 1979). Buxton (1960) stressed the difficulty in understanding how Agaricale dependent and often monophagous species of Mycetophilidae can maintain themselves, as the available period of sporophores can be restricted to a few weeks in autumn only. The gnats must follow this transitory occurrence of sporophores in autumn. If no more than one generation is produced, the females must wait for the next autumn's sporophores to emerge before oviposition. Further, if the time females are able to store sperm received during copulation is restricted, this may necessitate a delayed mating, which explain why both sexes hibernate and seem to mate in spring. Hibernating species of Culicidae are always females (Tollet 1959, Jefferson 1983). In these species, mating occurs before the winter and only the fertilized females hibernate. Thus, the need for spring proximity of the sexes is obviated (Danks 1978). Oviposition probably takes place in a much shorter time after emergence from the hibernation site than for Mycetophilidae. For the common mosquito Culex pipiens a seasonal obligatory diapause is probably involved to maintain the reproductive vigour of the population (Roubaud 1933).

Within Bolitophila it is nearly always females which occur in cave systems (e.g. Tollet 1955), while both sexes of Limonia nubeculosa are found (Jefferson 1983). Like most Mycetophilidae Bolitophila is a fungivorous genus feeding on Agaricales (Hackman \& Meinander 1979). According to Soós \& Papp (1988) they hibernate either as larvae or as adults. Aestivation by fe- males probably takes place between mating in spring and oviposition in autumn. The function of the sojourn underground is not understood in the case of Limonia nubeculosa (Jefferson 1983).

\section{Classification}

Based on the various kinds of affiliation and utilization of subterranean habitats, the Diptera in cave systems in southern Norway can be classified as follows:

A. Troglophiles of which larvae live in underground environments: Speolepta leptogaster.

B. Habitual trogloxenes:

I. Hibernators.

- Species where both sexes hibernate underground and mating takes place in the following spring (Mycetophilidae).

- Species where mating takes place prior to hibernation and only females are found underground during winter (Culicidae).

II. Aestivators.

- Species where both sexes seek cave systems during summer (Limoniidae).

- Species where mating takes place prior to aestivation and only females are found underground in summer (Bolitophilidae).

III. Species which seek cave systems independent of sex and season (Heleomyzidae, Trichoceridae).

IV. Opportunists (Chironomidae, Phoridae?, Dixidae?).

C. Accidental trogloxenes (most other Diptera).

Acknowledgements. I wish to express my gratitude to G. E. E. Søli, E. Willassen and T. Andersen, Museum of Zoology, University of Bergen for commenting on the manuscript and improving the language. Thanks are also due to T. A. Stormark for enthusiastic cooperation in the field. The following persons have kindly identified parts of the material or otherwise supported the project: T. Andersen, G. Bächli, C. Dahl, F. Florén, L. G. Jensen, M. Klann, S.E. Lauritzen, M. Nordseth, O. A. Sæther and E. Willassen. 


\section{References}

Burghele-Balacesco, A. 1965: Specii noi de Mycetophilidac cavernicole din România. - Lucr. Inst. Speol. 'E. Racovita' Acad. Repub. Pop. Rom. 4:171-179.

- 1966a: Diptères cavemicoles recueillis en Bulgarie. Int. J. Speleol. 2:303-308.

- 1966b: Les Mycetophilidae (Diptères) cavernicoles de la collection Biospeologica $\left(\mathrm{IV}^{\mathrm{e}}-\mathrm{VIII}^{\mathrm{e}}\right.$ séries des "Grottes visitées"). — Int. J. Speleol. 2:319-334.

Buxton, P. A. 1960: British Diptera associated with fungi. III. Flies of all families reared from about 150 species of fungi, — Entomol. Mon. Mag. 96:61-94.

Chandler, P. J. 1978: Notes on the Holarctic species of Pseudexechia Tuomikoski (Diptera: Mycetophilidae), with the description of a new British species. Entomol. Rec. J. Var. 90:44-51.

Dahl, C. 1970: Distribution, phenology and adaptation to arctic environment in Trichoceridae (Diptera). — Oikos 21:185-202.

Danks, H. V. 1978: Modes of seasonal adaptation in the insects I. Winter survival. - Can. Entomol. 110:11671205.

Gislén, T. \& Brinck, P. 1950: Subterranean waters on Gotland with special regard to the Lummelunda current II. Environmental conditions, plant and animal life, immigration problems. - Acta Univ. Lund, 46(6):1-81.

Glennie, E. A. 1965: The nature of cave fauna. - Biol. Rec. Cave Res. Group Great Br. 9:3-6.

Hackman, W. 1963: Studies on the Dipterous fauna in burrows of voles (Microtus, Clethrionomys) in Finland. - Acta Zool. Fennica 102. 64 pp.

- 1980: A check list of the Finnish Diptera 1. Nematocera and Brachycera (s. str.). - Notulae Entomol. 60:17-48.

Hackman, W. \& Meinander, M. 1979: Diptera feeding as larvae on macrofungi in Finland. - Ann. Zool. Fennici $16: 50-83$.

Hazelton, M. 1955-60: Fauna collected from caves as recorded in the C.R.G. Fauna records. - Biol. Suppl. Cave Res. Group Great Br. 1:1-12, 2a:1-13, 2b:1-15, $3: 1-20,4: 1-18,5: 1-21$.

- 1960: Fauna collected from caves, mines and wells as recorded in the C.R.G. Fauna records. - Biol. Rec. Cave Res. Group Great Br. 6:1-31.

- 1961: Fauna collected from caves, mines and wells as recorded in the C.R.G. Recent invertebrate fauna records. - Biol. Rec. Cave Res. Group Great Br. 7:1-64.

- 1963: Fauna collected from caves, mines and wells as recorded in the C.R.G. Recent invertebrate fauna records. - Biol. Rec. Cave Res. Group Great Br. 8:1-41.

- 1965a: Biological records. Additions \& corrections to former numbers. - Biol. Rec. Cave Res. Group Great Br. 9:7-9.

- 1965b: Biological records 1963. - Biol. Rec. Cave Res. Group Great Br. 9:10-19.

Hippa, H. \& Koponen, S. 1988: The Arthropod Fauna of Grönligrotta, Norway. - Cave Sci. 15:117-119.

Husson, R. 1936: Contribution à l'étude de la faune des cavités souterraines artificielles. - Ann. Sci. Nat. Zool. 19:5-30.
- 1947: Diptères des galeries de mines de France. Notes Biospéleol. 1:37-52.

Hutson, A. M. 1978: Caves. -- In: Stubbs, A. \& Chandler, P. (ed.), A Dipterist's handbook. Amateur Entomol. 15:134-137.

Hutson, A. M., Ackland, D. M. \& Kidd, L. N. 1980: Mycetophilidae (Bolitophilinae, Ditomyiinae, Diadocidiinae, Keroplatinae, Sciophilinae and Manotinae). - Handb. Ident. Br. Insects 9(3):1-111.

Jeannel, R. 1926: Faune cavernicole de la France. - P. Lechevalier, Paris. 334 pp.

Jefferson, G. T. 1983: The threshold fauna. — Stud. Speleol. 4:53-58.

Krogerus, R. 1926: Djurlivet i Torhola grotta. - Notulae Entomol. 6:23-24.

Matile, L. 1970: Les Diptères cavernicoles. - Ann. Speleol. 25:179-222.

Østbye, E., Lauritzen, S.-E., Fjellberg, A., Hauge, E., Leinaas, H. P., Ottesen, P. \& Solhøy, T. 1987: Invertebrates of Norwegian caves I. Gastropoda, Oligochaeta, Araneae, Acari, Amphipoda, Collembola, Coleoptera, Lepidoptera and Diptera. - Fauna Norv. (Ser. A) 8:43-64.

Plassmann, t. 1989: Winteraktivität von adulten Pilzmücken eines Birkenbestandes des östlichen schlewigholsteinishen Hügellandes (Diptera, Nematocera, Mycetophilidae). - Entomofauna 10:257-272.

Plassmann, E. \& Weber, D. 1988: Die Pilzmückenfauna des Brunnenstollens $(6612 / 18)$ bei Trippstadt/Pfälzerwald. - Pfälzer Heimat 3:137-139.

Racovitza, E. G. 1907: Essai sur les problèmes biospéologiques, - Biospéologica 1:371-488.

Roubaud, E. 1933: Essai synthétique sur la vie du moustique commun (Culex pipiens). L'evolution humaine et les adaptations biologiques du moustique. Ann. Sci. Nat. Zool. 16:5-168.

Sandvik, K. O. 1977: Befaringer av malmforekomster, Hordaland 1977. - Norges Geol. Unders. Vestlandsprg. 1560/17C: 1-58.

Soós, Á. \& Papp, L. 1988: Catalogue of palaearctic Diptera. 3. Ceratopogonidae - Mycetophilidae. - Akadémiai Kiadó. Budapest. 448 pp.

- 1991: Catalogue of palaearctic Diptera. 2. Psychodidae - Chironomidae. -- Akadémiai Kiadó. Budapest. 499 pp.

Tercafs, R. \& Thinès, G. 1973: Étude des déclencheurs visuels intervenant lors de la pénétration souterraine de Scoliopteryx libatrix L. et Triphosa dubitata L. (Lépidoptères trogloxènes). — Ann. Spéléol. 28:177181.

Tollet, R. 1955: Etudes Biospéologiques XXXVI Révision des Mycetophilidae cavernicoles de Transylvanie (Diptera Nematocera), recueillis par R. Leruth. - Mém Soc. R. Entomol. Belg. 27:443-465.

- 1959: Contribution à l'étude des Diptères cavernicoles des grottes d'Italie et de Suisse et description de deux Mycetophilidae nouveaux. - Bull. Ann. Soc. R. Entomol. Belg. 95:205-231.

Received 18.IX.1992 